\title{
On the Methanol-Hydrogen Peroxide Fuel Cell.
}

\author{
Chiaki IwakURA*, Hideo TAmura* and Toshio Ishino** \\ * Department of Chemical Technology, Faculty of Engineering, Osaka University, \\ Higashinoda-9, Miyakojima, Osaka, Japan \\ ** Himeji Technical College, Idei, Himeji, Hyogo, Japan
}

Received July 4, 1967

\begin{abstract}
Cathodic polarization characteristics of a hydrogen peroxide electrode and the performances of the methanol fuel cell in all-liquid system are investigated using hydrogen peroxide as an oxidant in order to eliminate the problems appeared in gas-liquid system. Characteristics of the hydrogen peroxide electrode are improved with the high hydrogen peroxide and the low methanol concentrations and with the rising temperature. Using "Selemion AAT" as a separator, performance of the methanol fuel cell is significantly feasible when the catholyte is continuously fed into the cathode chamber. Furthermore, the cell using the doubly activated nickel electrodes shows better performance than that of the platinized nickel electrode.
\end{abstract}

\section{Introduction}

In general, air or oxygen has been used as an oxidant in dissolved methanol fuel cells. In such a gas-liquid system, however, the porous cathode is required and as a result, the performance may occasionally fall due to the electrode wetting. In this paper, cathodic polarization characteristics of the hydrogen peroxide electrode and the performances of the methanol fuel cell in all-liquid system are investigated using hydrogen peroxide as an oxidant in order to eliminate the above mentioned problems.

\section{Experimental}

An apparatus used in the cathodic polarization measurements* is shown in Fig. 1(a) The test electrode was cathodically polarized with a current let flow between this electrode and two counter electrodes and the potentials were measured against a mercury oxide reference electrode at $50^{\circ} \mathrm{C}$ by the direct method with a Luggin-capillary. In these measurements, the electrolyte was a mixture of $6 \mathrm{~N} \mathrm{KOH}, \mathrm{CH}_{3} \mathrm{OH}$ and $\mathrm{H}_{2} \mathrm{O}_{2}$.

The cell* for discharging performance measurements is given in Fig. 1(b). The 
electrolytic cell was made of acryl resin and was separated by a separator into the anode and the cathode chambers. The Anolyte and catholyte were $(6 N \mathrm{KOH}$ $\left.+\mathrm{CH}_{3} \mathrm{OH}\right)$ and $\left(6 \mathrm{~N} \mathrm{KOH}+\mathrm{H}_{2} \mathrm{O}_{2}\right)$, respectively. The former was fed from the reservoir into the chamber through the bottom via the preheater portion by head and let overflow at the top of the cell.

\section{Results and Discussion}

\subsection{Cathodic Polarization Characteristics of Hydrogen Peroxide Electrode}

At first some problems in the selection of electrode catalysts are taking place. For example, the catalysts at fuel and oxidant electrodes in such an all-liquid system fuel cell must be selective for electrochemical reactions of methanol and hydrogen peroxide, respectively.

In the first place, cathodic polarization characteristics of the various electrodes were measured and some results of them are shown in Fig. 2. Silver catalyst seemed to be the best of all the electrode catalyst studied for reduction of hydrogen peroxide, and considerable reduction seemed to occur even on smooth silver plate.

- In this experiment, two ways were employed for adding hydrogen peroxide into alkaline solution. One is continuous feeding of the mixed solution during the experiment and the other is batch system for addition of it before the experiment. In the latter system, the electrode characteristics were influenced greatly by the concentration of hydrogen peroxide as

\footnotetext{
*The electrodes used in these experiments were $4 \times 1.5 \mathrm{~cm}$-size. The current densities were cal_culated by using the available surface area of 12 $\mathrm{cm}^{2}$ (the sum of the front and the back of the electrode). In truth, however, the available area must be much smaller than $12 \mathrm{~cm}^{2}$, and the net current densities would be larger than the values described in the figures.
}
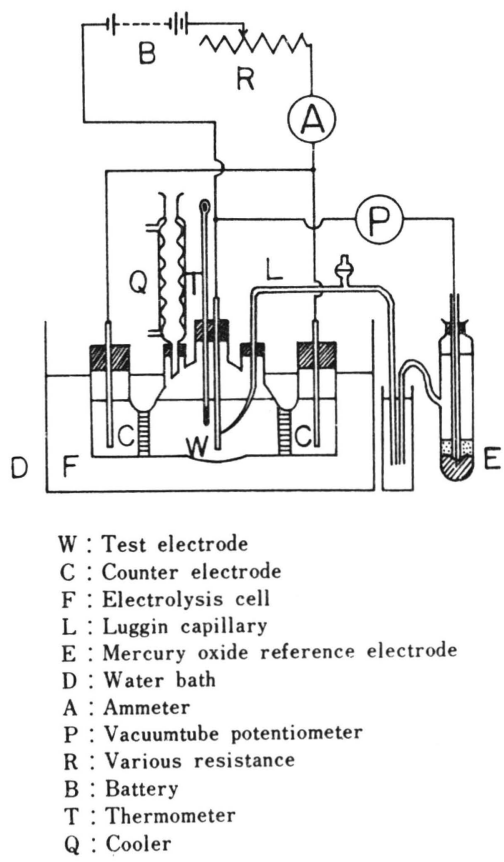

Fig. 1(a) Apparatus used in cathodic polarization measurements.

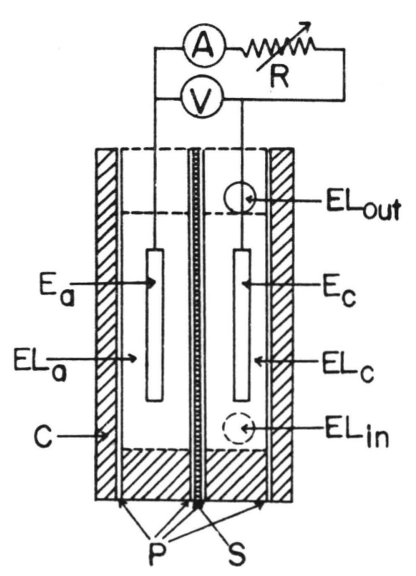

$\begin{array}{ll}\text { A : } & \text { Ammeter } \\ \text { V: } & \text { Voltmeter } \\ \text { R: } & \text { Various resistance } \\ \text { S: } & \text { Diaphragm (Separator) } \\ \text { P: } & \text { Packing } \\ \text { C: } & \text { Plastic cell } \\ \text { Ea: } & \text { Anode } \\ \text { Ec: } & \text { Cathode } \\ \text { ELa: } & \text { Anolyte } \\ \text { ELc: } & \text { Catholyte } \\ \text { ELin : Inlet of Catholyte } \\ \text { ELout : Outlet of Catholyte }\end{array}$

Fig. 1(b) Cell for discharging performance measurements. 


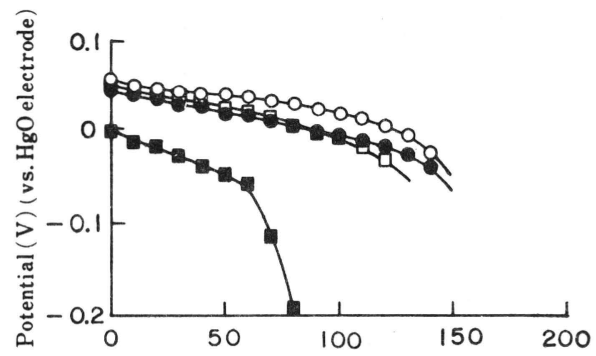

Current density $\left(\mathrm{mA} / 12 \mathrm{~cm}^{2}\right)$

Electrolyte : $6 \mathrm{NKOH}+3$ mole $\mathrm{CH}_{3} \mathrm{OH}+0.05$ mole $\mathrm{H}_{2} \mathrm{O}_{2}$ Temperature : $50^{\circ} \mathrm{C}$

Electrode catalyst :

- - - : Ag- Ag plate

Composition of plating: $240 \mathrm{~g} / \mathrm{l} \mathrm{AgNO}_{3}+33.75 \mathrm{~g} / l$

$\mathrm{KCN}+36 \mathrm{~g} / l \mathrm{~K}_{2} \mathrm{CO}_{3}+112.5 \mathrm{~g} / l \mathrm{KNO}_{3}$,

Plating condition: ca. $0.3 \mathrm{~A} / 12 \mathrm{~cm}^{2}, 10 \mathrm{~min}$,

- - : Smooth Ag plate

- - : Ag-Ni plate

Composition of plating and plating condi-

tion are the same as described above

-- - : Smooth Ni plate

Fig. 2 Cathodic polarization characteristics of the various electrodes.

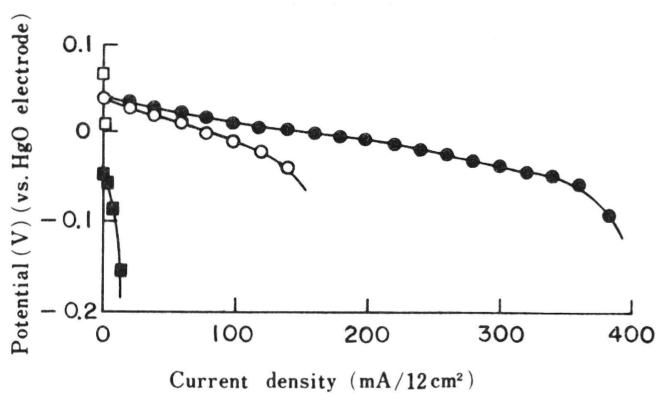

Electrode: Smooth Ag plate

Methanol concentration : $3 \mathrm{~mole} / 500 \mathrm{~m} /$-electrolyte

Temperature : $50^{\circ} \mathrm{C}$

Hydrogen peroxide concentration:

———: $0 \mathrm{~mole} / 500 \mathrm{~m} /$-electrolyte

$-: 0.01$

$-\circ-: 0.05$

$-\bullet-0.15$

Fig. 3 Effects of hydrogen peroxide concentration on cathodic polarization characteristic.

can be seen in Fig. 3. Electrodes will polarize rapidly when they are not receiving sufficient oxidant.

Polarization measurements were carried out at different temperature under

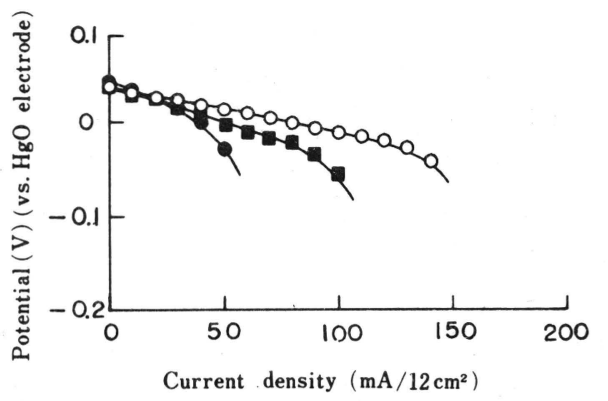

Electrode: Smooth $\mathrm{Ag}$ plate.

Electrolyte: $6 \mathrm{NKOH}+3$ mole $\mathrm{CH}_{3} \mathrm{OH}+0.05$ mole $\mathrm{H}_{2} \mathrm{O}_{2}$

Temperature :

$$
\begin{array}{rr}
--: & 20^{\circ} \mathrm{C} \\
--: & 36.5^{\circ} \mathrm{C} \\
-0--: \quad 50^{\circ} \mathrm{C}
\end{array}
$$

Fig. 4 Effects of temperature on cathodic polarization characteristic.

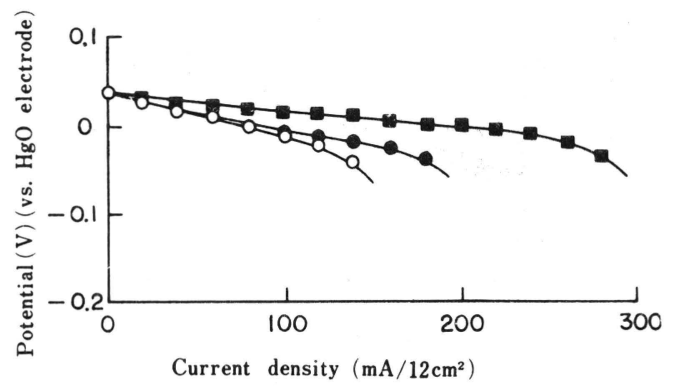

Electrode: Smooth Ag plate

Hydrogen peroxide concentration : $0.05 \mathrm{~mole} / 500 \mathrm{~m} /$-electrolyte Temperature : $50^{\circ} \mathrm{C}$

Methanol concentration:

$$
\begin{aligned}
& -\circ-: 3 \mathrm{~mole} / 50 \mathrm{~cm} l \text {-electrolyte } \\
& -\bullet-: 1.5 \\
& --: 0
\end{aligned}
$$

Fig. 5 Effects of methanol concentration on cathodic polarization characteristic.

the constant concentration of hydrogen peroxide (Fig. 4). Improved characteristics with rising the temperature can be interpreted by the consideration that the reactivity of hydrogen peroxide would increase. Decomposition rate of hydrogen peroxide into oxygen and water has been reported to increase with rising the temperature, high concentration of alkaline solution and the existence of the catalyst, 
such as silver ${ }^{1)}$. Therefore, it is considerable that oxygen produced by the decomposition of hydrogen peroxide may be involved in the electrode reaction.

The effect of methanol concentration on the hydrogen peroxide electrode is given in Fig. 5. As can be seen from the results, the characteristic of the hydrogen peroxide electrode improved with decreasing the methanol content. This shows that methanol can react a little on smooth silver and that the chemical reaction of methanol with hydrogen peroxide may occur. These are in contrast to the result obtained at room temperature by Grimes et. al. ${ }^{2}$ )

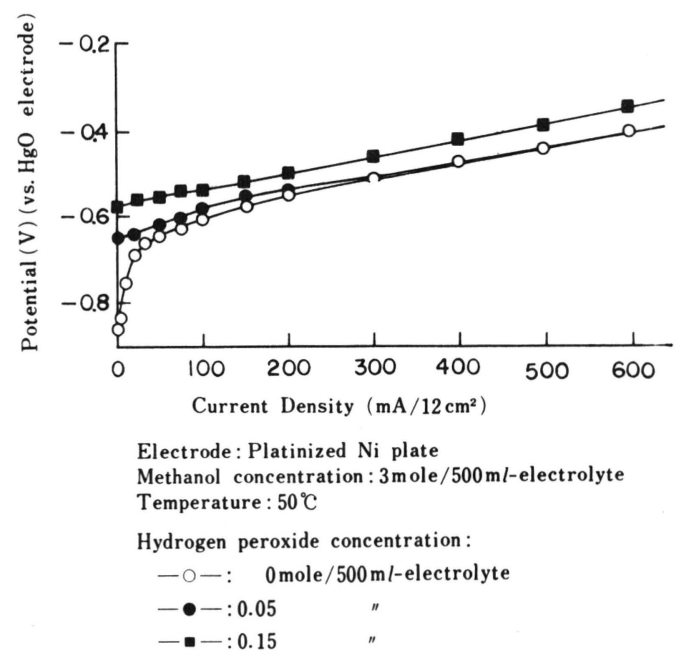

Fig. 6 Effects of hydrogen peroxide concentration on anodic polarization characteristic of the anode.

For reference, the effect of hydrogen peroxide concentration on the anodic characteristics of the fuel electrode were investigated. Fig. 6 represents the result, which shows that hydrogen peroxide also reacts at the fuel electrode, and leads to clear difference in the characteristics of the fuel electrodes. It is therefore necessary to place a diaphragm between the methanol and the hydrogen peroxide electrodes forming two chambers for the practical operation of the cell.

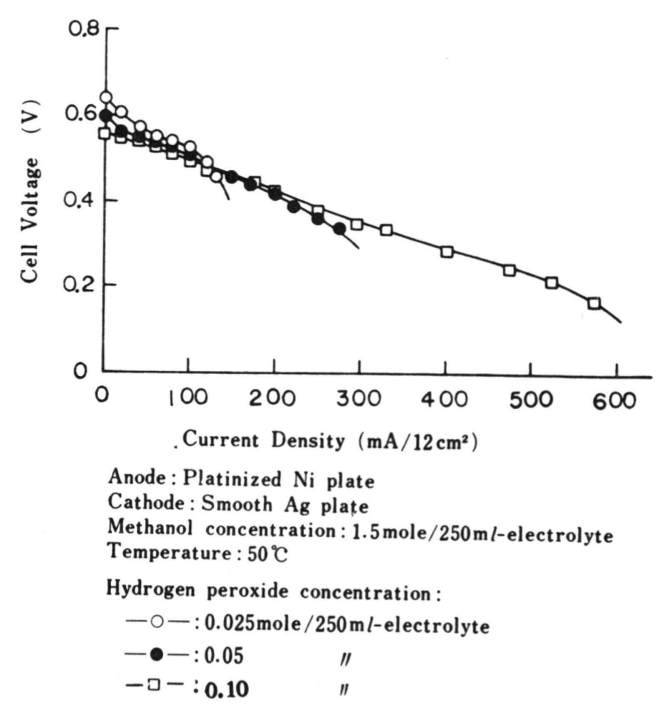

Fig. 7 Effects of hydrogen peroxide concentration on discharging characteristic.

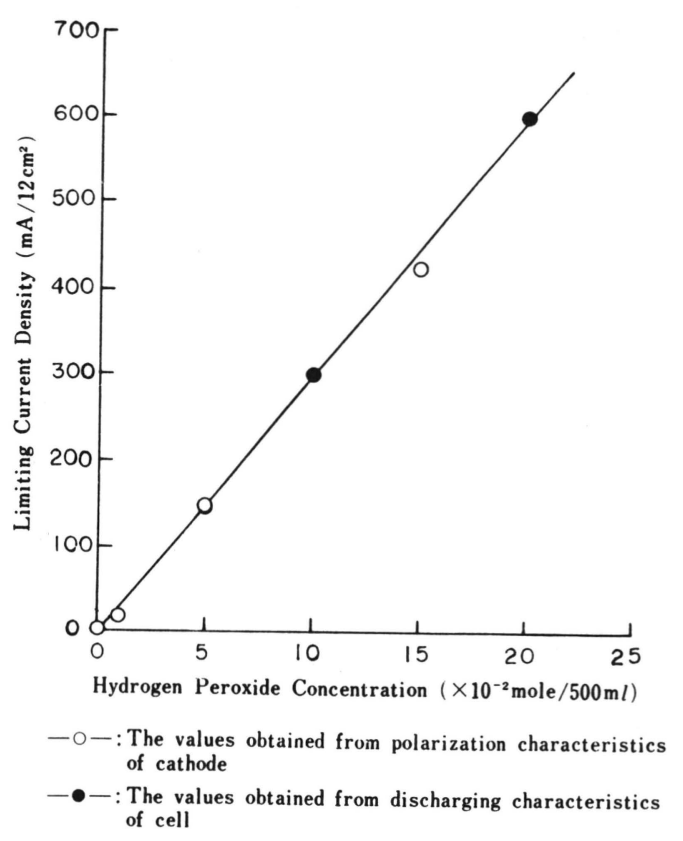

Fig. 8 The relations between hydrogen pe $r$ -oxide concentration and the limiting current density. 


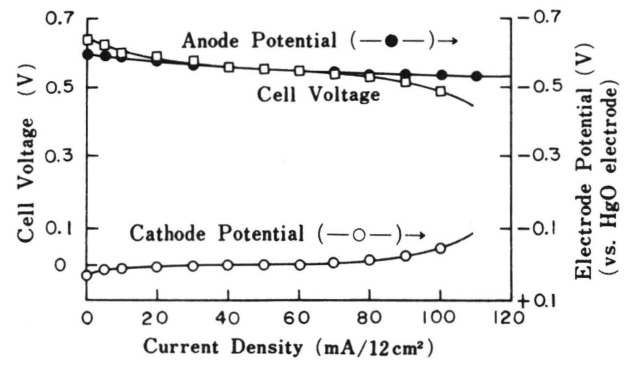

The same measuring conditions as described in Fig. 7. except for hydrogen peroxide concentration (0.025 mole $/ 250 \mathrm{ml}$-electrolyte)

Fig. 9 Cell discharging characteristic and the electrode potentials.

\subsection{Discharging Characteristics of the Cell}

The preliminary cell was set up using platinized nickel plate and smooth silver plate as anode and cathode respectively, and their discharging characteristics were examined. In the first place, the examination was carried out without a diaphragm in batch system of hydrogen peroxide addition. The results are given in Fig. 7, from which it can be seen that the open circuit voltage is lower but that the obtainable current become larger with increasing the hydrogen peroxide content. This is the same tendency as obtained in Fig. 3. These two kinds of experiments can be summarized in Fig. 8. A linear relation was found between the limiting current and the hydrogen peroxide concentration. The dependence of the cell limiting current on the characteristic of hydrogen peroxide electrode was also observed in Fig. 9.

The discharging characteristics were examined using an ion-exchange membrane and filter cloth as separator, and the results are shwon in Figs. 10 and 11. The cell with separators showed the open circuit voltage of higher than 0.8 volts, sometimes over 0.9 volts. With the filter cloth, good results could not be obtained in the view of the limiting current density,

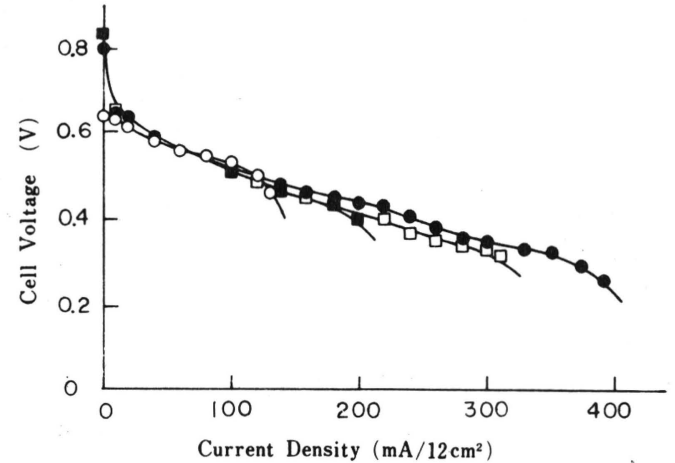

Anode : Platinized Ni plate. Methanol concentration : 1.5 mole/125 ml-electrolyte. Cathode: Smooth $\mathrm{Ag}$ plate. Hydrogen peroxide concentration : $0.025 \mathrm{~mole} / 125 \mathrm{~m} /$-electrolyte. Ion exchange membrane as a diaphragm:

- O-: without diaphragm.

- - : Selemion AAT (Anion exchange membrane)

- - : Selemion CMV (Cation

-- : Selemion DMT (Anion

Fig. 10 Effects of diaphragms on cell discharging characteristic (Part 1)

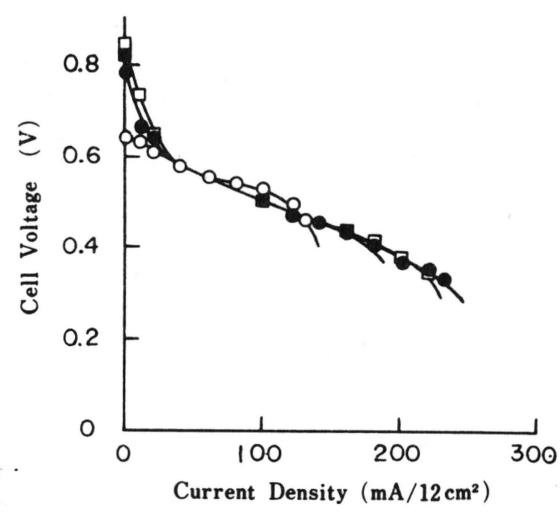

The same measuring conditions as described in Fig. 10 except for the followings:

Filter cloth as a diaphragm.

-O-: Without diaphragm.

- - : KA $\cdot 301$ (T)

—ロー: Tv 107

- - : $1028-\mathrm{B}$

Fig. 11 Effects of diaphragms on cell discharging characteristics. (Part 2)

whereas the remarkable effect was observed with the ion-exchange membrane. Especially "Selemion AAT" (anion exchange membrane) was the most cffective in this study. "Selemion DMT" (anion 
exchange membrane) was not good, probably because it was a diffusion dialysis membrane. In the case of filter cloth, separating ability of the anolyte from the catholyte may not be good and then hydrogen peroxide may be consumed by the reaction of hydrogen peroxide with methanol and the intermediates and by its reaction at the anode.

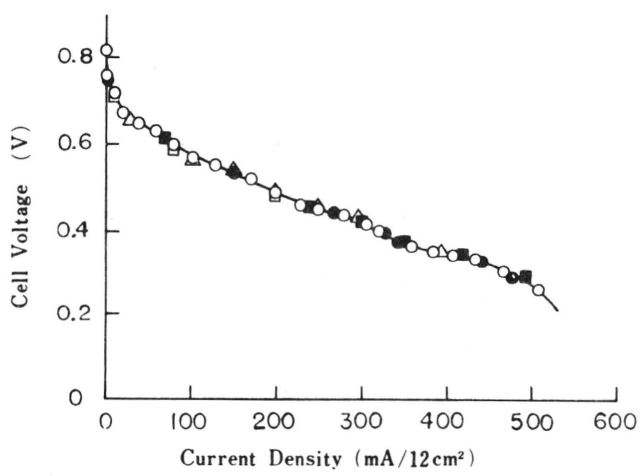

Anode : Platinized Ni plate, Methanol concentration : 1.5 mole $/ 125 \mathrm{~m} /$-electrolyte: Cathode : Smooth Ag plate, Hydrogen peroxide concentration: $0.025 \mathrm{~mole} / 125 \mathrm{~m} /$-electrolyte.

Flow rate of catholyte $: 25 \sim 30 \mathrm{~m} / / \mathrm{min}$.

Diaphragm : Selemion AAT.

Temperature : $50^{\circ} \mathrm{C}$

Measuring order:- $-:$ : 1 st, - - : 2 nd,

$-\square-:: 3 \mathrm{rd},-\square-: 4 \mathrm{th},-\triangle-: 5$ th measurement.

Fig. 12 Cell discharging characteristic in continuous feeding system of catholyte.

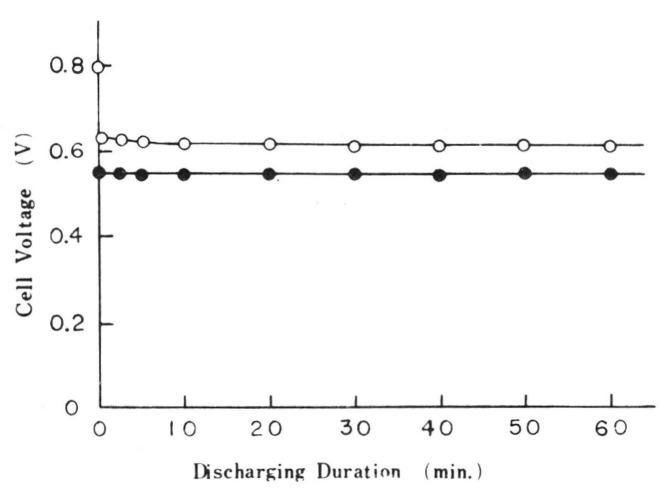

The same measurings conditions as described in Fig. 12 except for the followings.

Discharging current density Mean frow rate of catholyte. $\begin{array}{rrr}-O-: & 60 \mathrm{~mA} / 12 \mathrm{~cm}^{2} & 15 \mathrm{~m} / / \mathrm{min} . \\ - & 120 \mathrm{~mA} " & 21 "\end{array}$

Fig. 13 Cell discharging characteristics at constant current.
The limiting current density during discharge of the cell depends on the characteristic of hydrogen peroxide electrode, and the catholyte must be continuously fed into the chamber. Figs. 12 and 13 represent the discharging characteristics measured under such conditions. In case of continuous feeding of the electrolyte, the decline of the limiting current density and the drop of the cell voltage owing to the decreasing concentration of hydrogen peroxide could be eliminated and the cell performance were improved significantly. The observed cell voltages were 0.82 volts at open circuit and about 0.3 volts at a current of $500 \mathrm{~mA}$ per unit cell. The flow rate of the catholyte did not influenced on a cell voltage over the wide range of the rate during the measurements.

The cell performance was also examined when the doubly activated nickel plate electrode ${ }^{3)}$ or the non-electrolytic doubly

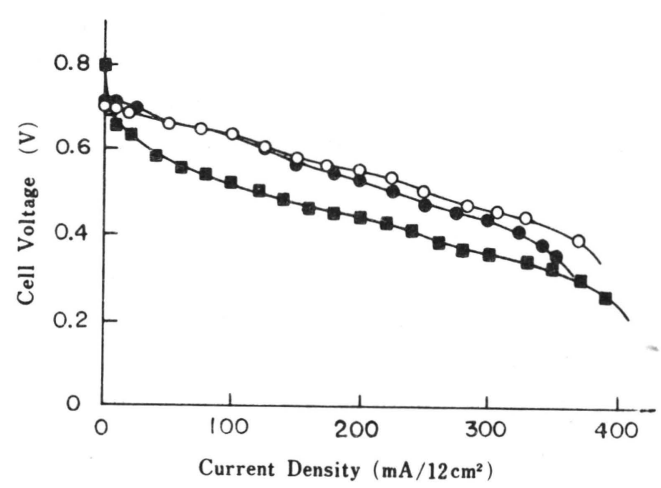

Cathode: Smooth Ag plate, Hydrogen peroxide concentration $: 0.025 \mathrm{~mole} / 125 \mathrm{ml}$-electrolyte, Methanol concentration: $1.5 \mathrm{~mole} / 125 \mathrm{~m} /$-electrolyte, Temperature : $50^{\circ} \mathrm{C}$

Anode :

$$
\begin{aligned}
& \text { - }- \text { : Doubly activated } \mathrm{Ni} \text { plate } \\
& \left(\begin{array}{l}
\mathrm{Ni} \text { black }=25 \mathrm{~m} l \mathrm{HNO} / \mathrm{-watts} \text { bath, } 25 \mathrm{~A} / \mathrm{dm}^{2}, \\
\left.60 \mathrm{~min}, \mathrm{Pt} \text { black }=2 \mathrm{~A} / \mathrm{dm}^{2}, 10 \mathrm{~min}\right)
\end{array}\right. \\
& - \text { - Non-electrolytic doubly activated } \mathrm{Ni} \text { plate } \\
& \left(\begin{array}{l}
\mathrm{Ni} \text { black }=\text { the same as above described conditions, } \\
\mathrm{Pt} \text { black }=\text { non-electrolytic, } 20 \mathrm{~min} .
\end{array}\right) \\
& \text { - }: \text { Platinized Ni plate }\left(\mathrm{Pt} \text { black }=2 \mathrm{~A} / \mathrm{dm}^{2}, 10 \mathrm{~min} .\right)
\end{aligned}
$$

Fig. 14 Cell discharging characteristics, using doubly activated electrodes as an anode. 
activated nickel plate electrode $\left.{ }^{4}\right)$ was used in place of the platinized nickel plate as the fuel electrode(Fig. 14). These anodes were prepared with the procedures as described in the earlier papers. ${ }^{3), 4)}$ As expected from the data of the last paper, activation polarizations hardly appeared and the cell voltage became about 0.1 volts higher than that with the platinized electrode under the same conditions. The cell voltage was about 0.64 volts at a current of $100 \mathrm{~mA}$. Thus, the superiority of the doubly activated electrodes can be admitted.

Since the hydrogen peroxide electrode is the most important factor affecting the cell performance in the present fuel cell, the electrode characteristics described here must be improved further by any other methods in order to obtain larger current.

\section{Summary}

In this paper, cathodic polarization characteristics of the hydrogen peroxide electrode and the discharging characteristics of the methanol-hydrogen peroxide fuel cell are investigated.

The results can be summarized as follows;

(1) Silver is the excellent catalyst for reduction of hydrogen peroxide and considerable reduction of hydrogen peroxide can occur even on smooth silver plate.

(2) Cathodic polarization characteristics of the hydrogen peroxide electrode are improved with the high hydrogen peroxide and the low methanol concentrations and with rising the temperature. On the other hand, fuel electrode are reduced with increasing the concentration of hydrogen peroxide.

(3) It is, therefore, necessary to separate the anode and cathode compartments with a membrane. "Selemion AAT" is the most effective separator in this study.

(4) Limiting current density during discharge of the cell depends on the hydrogen peroxide electrode, and the catholyte must be continuously fed into the cathode chamber. Under such conditions, the cell performance are improved significantly.

(5) When the doubly activated or the non-electrolytic doubly activated nickel plate is used in place of the platinized nickel plate as the fuel electrode, the cell voltage become by about 0.1 volts higher than that with the platinized nickel plate electrode over the wide range of the current.

\section{Literature:}

1) S. Mizushima, et.al., "Encyclopaedia Chimica” p. 364 (1960) Kyoritsu Shuppan, Tokyo.

2) P. G. Grimes, B. Fiedler, J. Adam, "Proc. 15th Ann. Power Sources Conf.” p. 29 (1961).

3) H. Tamura, C. Iwakura, S. Iwanaga, T. Ishino, Denki Kagaku 34, 270 (1966).

4) C. Iwakura, H. Tamura, T. Ishino, ibid. 34, 817 (1966). 